\title{
Distribution, Movement and Abundance of Polar Bears in Lancaster Sound, Northwest Territories
}

\author{
R.E. SCHWEINSBURG, ${ }^{1}$ L.J. LEE' and P.B. LATOUR ${ }^{1}$
}

\begin{abstract}
Mark-recapture studies show that polar bears are distributed at varying densities throughout Lancaster Sound during winter and spring. Major concentrations occur along the north and south coasts and the transverse floe edge at the mouth of the sound. As the ice melts, some bears move west whereas others move to nearby land areas. There is some evidence that as the ice forms, polar bears return from their summer locations to eastern Lancaster Sound. Polar bears of Lancaster Sound are part of the larger population whose western range extends to Barrow Strait, Prince Regent Inlet, Wellington Channel and Jones Sound. The southern and eastern range limits are unknown although this population may extend at least to Clyde River on northeastern Baffin Island and probably to Greenland. Maternity denning appears to be widespread over the study area probably because of the abundance of suitable habitat. We estimated a population of $1031 \pm 236$ polar bears in Lancaster Sound during 1979; however, more estimates are needed to determine if this relatively high number is normal for the area.
\end{abstract}

Key words: polar bear, distribution, movement, abundance, Baffin Bay, Lancaster Sound, summer retreat, denning

RÉSUMÉ. Les études de "marquage-recapture" démontrent que les ours polaires sont répartis selon des densités variables à travers le détroit de Lancaster durant l'hiver et le printemps. Les concentrations les plus importantes se trouvent le long des côtes nord et sud et sur la bordure transversale de la glace en dérive à l'embouchure du détroit. A la fonte des glaces, certains ours déménagent à l'ouest alors que les autres déménagent sur les terres à proximité. Certains faits indiquent que, lorsque la période de formation des glaces est revenue, les ours polaires quittent leur territoire d'été pour revenir à l'est du détroit de Lancaster. Les ours polaires du détroit de Lancaster font partie d'une plus grande population dont l'habitat s'étend vers l'ouest jusqu'au détroit de Barrow, à l'anse du Prince Regent, au canal Wellington et au détroit de Jones. Les limites sud et est de leur habitat sont inconnues quoique cette population peut s'étendre au moins jusqu'à la rivière Clyde sur la côte nord de l'île de Baffin et probablement jusqu'au Groënland. Il semble que les repaires pour la mise à bas sont parsemés au travers de toute la région à l'étude: cette distribution découle vraisemblablement d'une abondance d'habitats propices à cette activité. Nous avons estimé la population à $1031 \pm 236$ ours polaires dans le détroit de Lancaster en 1949, cependant, plusieurs évaluations sont nécessaires afin de déterminer si ce nombre relativement élevé est normal pour cette region.

Traduit à Petro-Canada, St. John's.

\section{INTRODUCTION}

Studies of the biota of Lancaster Sound (Fig. 1) were begun in 1978 as part of the wider program of environmental studies related to offshore petroleum development. The polar bear (Ursus maritimus Phipps) was included in these studies because of its important place as a top carnivore in arctic marine food chains. Such studies are also desirable because Canada has ratified (1976; renewed 1981) the International Agreement for the Conservation of Polar Bears, which states in part:

"each Contracting party shall take appropriate action

to protect [polar bears and] the ecosystems of which

polar bears are a part, with special attention to habi-

tat components ... a and shall manage polar bears in accordance with sound conservation practices based on the best available scientific data."

Crude oil is extremely harmful to polar bears (DIAND, 1981); however, it has not been shown that bears will contact spilled oil in the wild. Nevertheless, the assumption that they will is the most logical until proven otherwise.

The Canadian Wildlife Service (CWS) studied polar bears in the Barrow Strait-Lancaster Sound area from 1970 to 1978, primarily in areas west of the Brodeur Peninsula (Stirling et al., 1978). Shorter studies have also been undertaken in central and eastern Lancaster Sound (Schweinsburg, 1976; Johnson et al., 1976; Schweinsburg et al., 1977). However, in each of the studies, data were lacking on the seasonal distribution and movements of polar bears in relation to ice and open water as well as on the size and geographical limits of the population(s) in eastern Lancaster Sound. 'The following study was undertaken to provide this information and to provide a baseline against which changes in polar bear populations in Lancaster Sound might be measured.

We report on polar bear research conducted in eastern Lancaster Sound in 1978 and 1979. In addition, we include pertinent summary information on hunter kill reports and other mark-recapture studies from the computerized retrieval file of the CWS and the NWT Wildlife Service (NWTWS).

\section{STUDY AREA}

Generally the land surrounding Lancaster Sound is of high relief with well-defined drainage patterns, although some regions such as northern Borden Peninsula have a rolling coastal plain. Large ice caps cover much of eastern Devon and Bylot islands, and smaller ice caps occur on Borden and Brodeur peninsulas. Detailed topographical descriptions are given in Dunbar and Greenaway (1956).

The following general description of ice conditions in the study area is from Dunbar and Greenaway (1956), Stirling et al. (1978) and this study. Ice formation begins in 


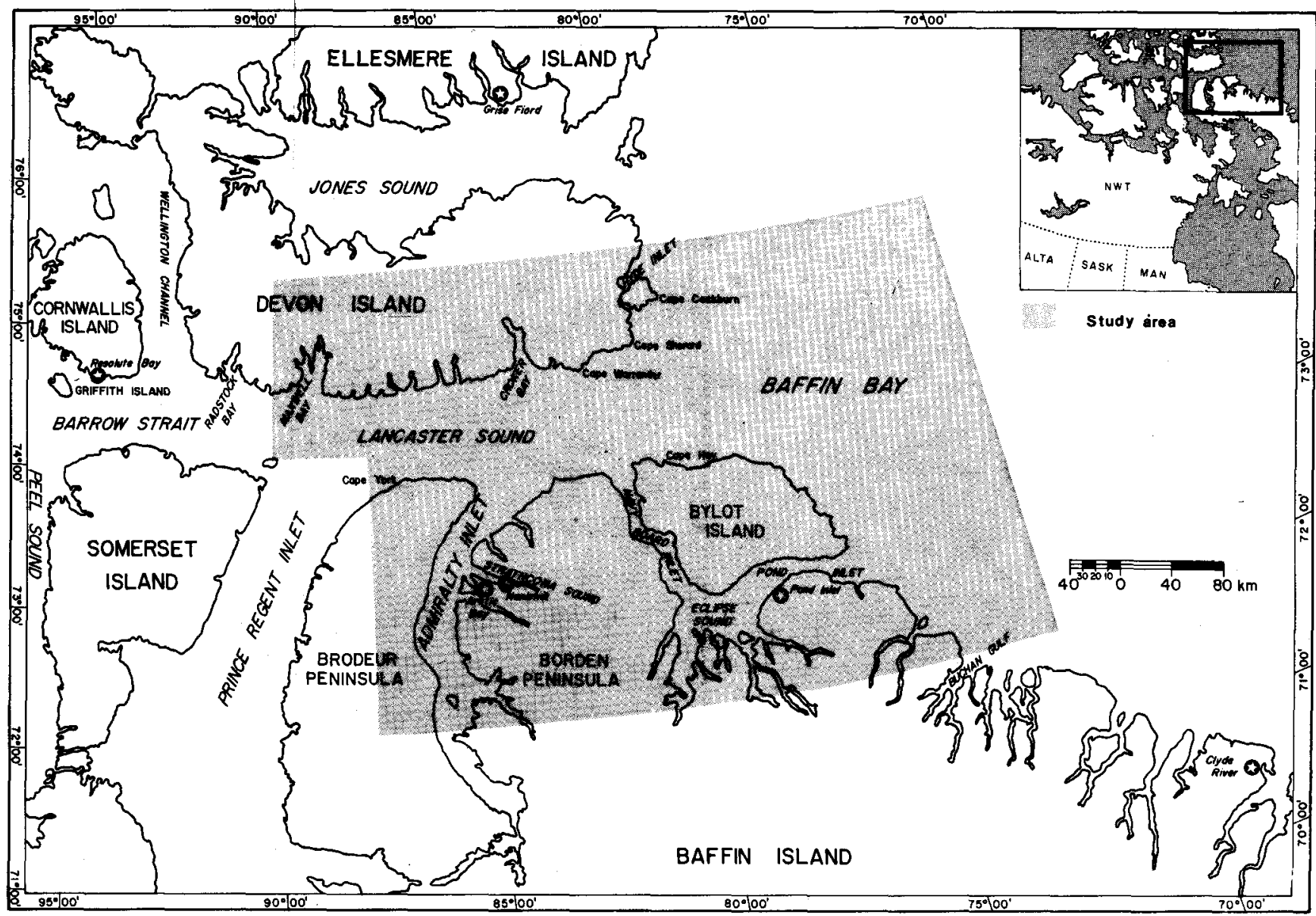

FIG. 1. Eastern Lancaster Sound and western Baffin Bay showing the study area (shaded).

the sheltered inlets in late September, and extends into Lancaster Sound and Barrow Strait during October. Admiralty, Navy Board and Pond inlets and Eclipse Sound usually freeze over entirely by November. The western side of Prince Regent Inlet is the last area to freeze over, possibly as a result of prevailing northwesterly winds. The pack ice covering Lancaster Sound usually remains fairly open all winter. A narrow lead approximately $5 \mathrm{~km}$ offshore frequently parallels the full length of southern Devon Island (Smith and Rigby, 1981). In some years a polynya extends from Griffith Island across Wellington Channel and Barrow Strait.

Ice loosens in Lancaster Sound and Barrow Strait in June as the lead along the Devon Island coast widens toward the open water southeast of Cornwallis Island. Ice from Wellington Channel and Peel Sound moves into Barrow Strait and drifts eastward through Lancaster Sound. By mid-August, the sound and most inlets at the north end of Baffin Island are ice-free, although ice remains for somewhat longer periods in deep bays such as Maxwell and Croker bays. Icebergs drift throughout Lancaster Sound during the summer. In both 1978 and 1979, spring breakup was delayed considerably and ice cover was heavier in comparison to "typical" years (Milne and Smiley, 1978).
A major difference between 1978 and 1979 was the more westerly position of the floe edge across Lancaster Sound in 1979 (Fig. 2). Descriptions of climate, physical and biological oceanography, and flora and fauna of the area are in companion articles in this issue.

\section{METHODOLOGY}

This study was conducted during April and May, 1978 and 1979. We chose a modified Peterson mark-recapture method (DeMaster et al., 1980) because (1) it yielded the most information per unit cost; (2) it was the technique being used in nearby on-going studies; and (3) it avoided the difficulties inherent in systematically counting a thinly dispersed, white animal in the variety of ice and snow conditions found in the study area. Mark-recapture locations provided information on seasonal distribution, movements and population ranges. Ratios of marked and recaptured bears yielded population estimates.

We used a helicopter to find and capture polar bears (Lentfer, 1968; Larsen, 1971). Intensive searches were conducted over ice habitats such as floe edges and areas of drifted pressure ridges, which had proved productive in past studies (Stirling et al., 1978). Little time was spent 


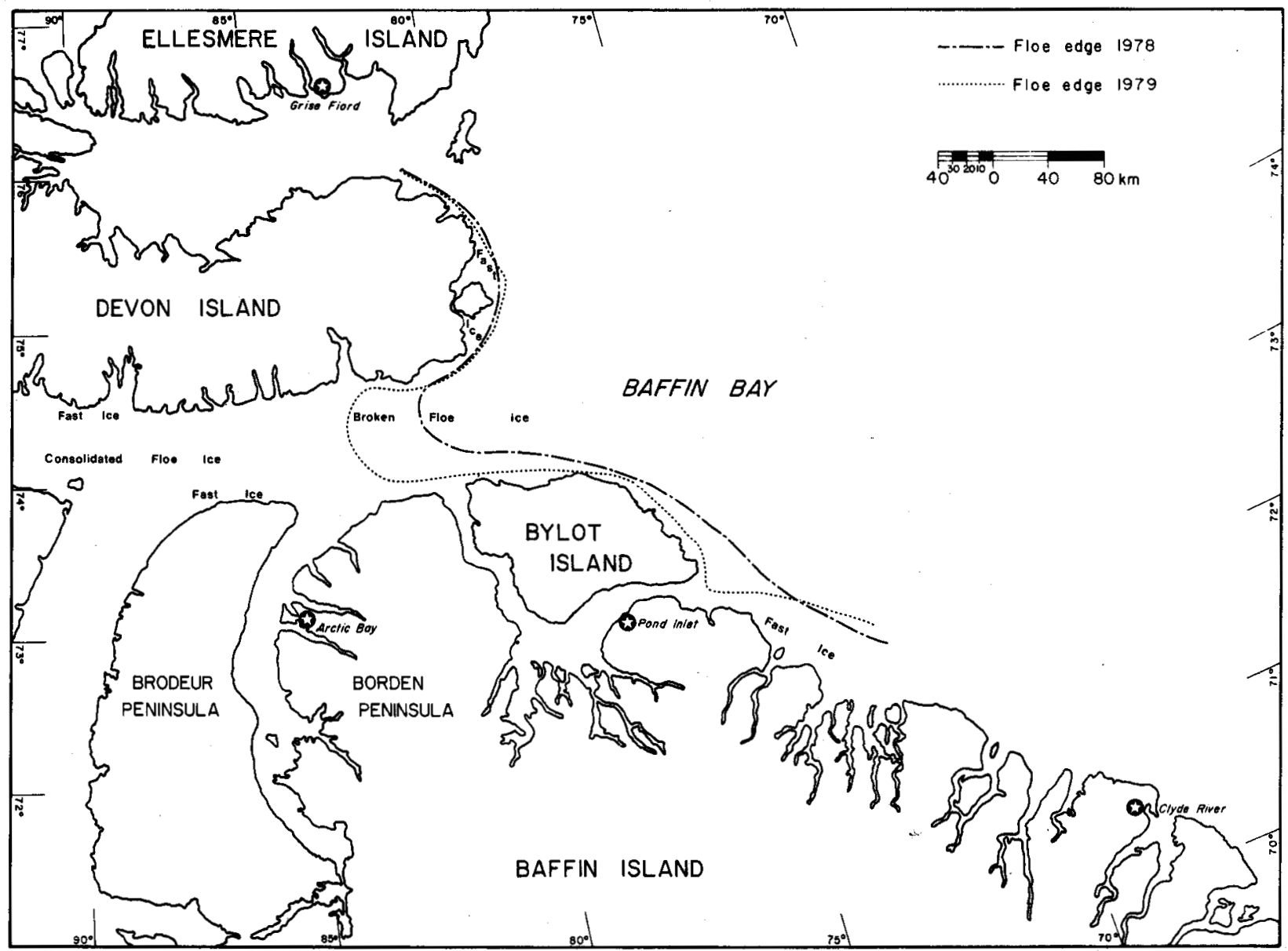

FIG. 2. Floe edge locations and ice conditions in Lancaster Sound during the 1978 and 1979 field seasons.

over broken floe ice because of safety considerations. The use of helicopters reduced problems of unequal vulnerability to capture because few bears were able to escape once spotted. Tracks were useful in determining concentration areas and distribution of bears. Tracks of females with cubs of the year were recorded to delineate coastal regions that might be important for maternity denning.

Most bears were immobilized with Sernylan (phencyclidine hydrochloride; Parke, Davis Co.), using approximately $2.2 \mathrm{mg} / \mathrm{kg}$ body weight. Some bears received the tranquilizer Sparine (promazine hydrochloride; Wyeth Laboratories Inc.) at approximately $1 / 4$ to $1 / 3$ the dosage of Sernylan. Two capture deaths occurred during the study. Once immobilized, bears were marked with individually numbered polyurethane ear tags (Western Industrial Research and Training Centre, Edmonton, Alberta). Because of the possibility of tag loss, each bear was also tattooed on both sides of its upper lip with a number corresponding to the ear tag. Bears were identifiable in all but a few cases. Data recorded for each bear included a weight estimate (determined by measuring the chest girth with a cattle-weight tape), sex, total length, physical condition, and any abnormalities. The first premolar was extracted for age determination. To facilitate subsequent identification from the air, we painted a large number (Lady Clairol hair dye) on the rump of each bear.

A reward was offered to hunters for the return of tags, lip tattoos and the lower jaws of bears that they killed. Ages of bears were determined by counting the annual growth rings in the cementum of teeth using the histological methods of Thomas and Bandy (1973) as modified by Stirling et al. (1978).

The population estimate for Lancaster Sound was calculated from capture-recapture data obtained during 1970-1979 for the shaded area in Fig. 1. Only recaptures, not hunter returns, were used in calculating population estimates; therefore all marked bears can be assumed reported. Although sampling was not instantaneous, unique marks prevented double counting of polar bears, thus eliminating the bias that prolonged sampling introduces.

\section{RESULTS}

\section{Distribution}

During April and May of 1978 and 1979 we captured 230 polar bears, 39 of which were recaptures from this or previous studies (Fig. 3). Sixty-nine resightings of 49 marked bears occurred during the study and six bears were resighted 


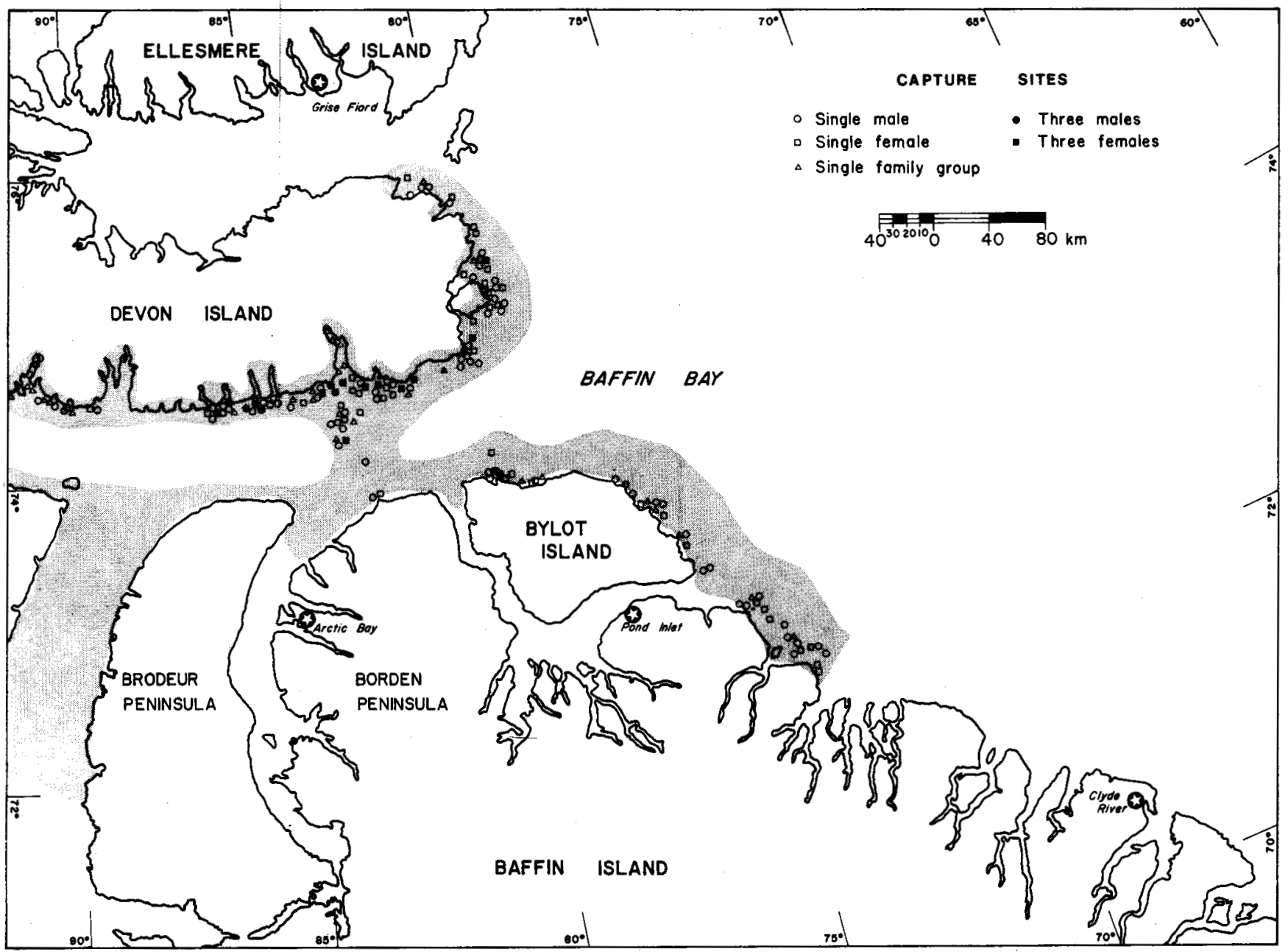

FIG. 3. Capture locations from this study and areas of concentrations of polar bears in late winter.

by Inuit during June and July of 1979 . Inuit hunters from Grise Fiord, Pond Inlet, Arctic Bay, Resolute Bay and Clyde River returned tags from 32 bears captured during this or previous studies. Seventeen of the recaptured bears had originally been captured outside the study area (Schweinsburg et al., 1977, Stirling et al., 1978).

TABLE 1. Summary of capture success by areas in 1978 and 1979 (expressed as bears $/ 1000 \mathrm{~km}$ flown)

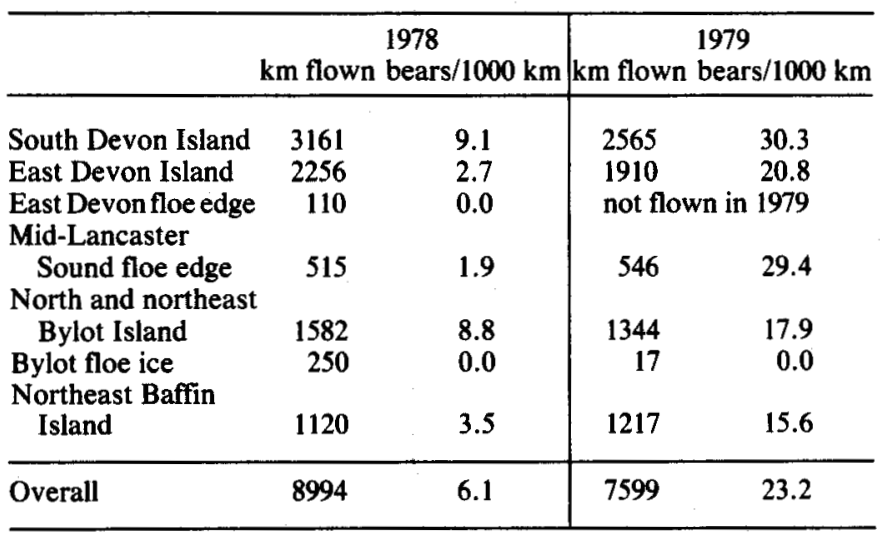

Our capture results, and subjective impressions based on track sightings, indicated that polar bears concentrated in certain parts of the study area during the late winter months (April and May). In both 1978 and 1979, the capture rate (bears captured $/ 1000 \mathrm{~km}$ flown) was highest along the south Devon coast (Table 1). Most captures were on the rough ice within $7 \mathrm{~km}$ of the coast and at the mouths of major inlets and bays. The capture rate at the mid-Lancaster Sound floe edge in 1979 was only slightly less than that for the south Devon coast. Although only three survey days were spent in mid-Lancaster Sound compared to eight days in south Devon Island, productivity was 29.4 bears $/ 1000$ $\mathrm{km}$ flown. Almost all bears were found within $2 \mathrm{~km}$ of the floe edge. In the east Devon region, captures were primarily in the Cape Sherard and Cape Cockburn areas, and in a system of refrozen leads at the mouth of Hyde Inlet. In this region, $73 \%(n=56)$ of bears found were on rough, fast ice, and 27\% ( $n=56)$ were at the floe edge.

In both 1978 and 1979, fewer bears were captured in the southern half of the study area. Capture locations were scattered along the entire landfast ice strip; $67 \%(n=24)$ of bears were found on landfast ice and $33 \%(n=24)$ at the 


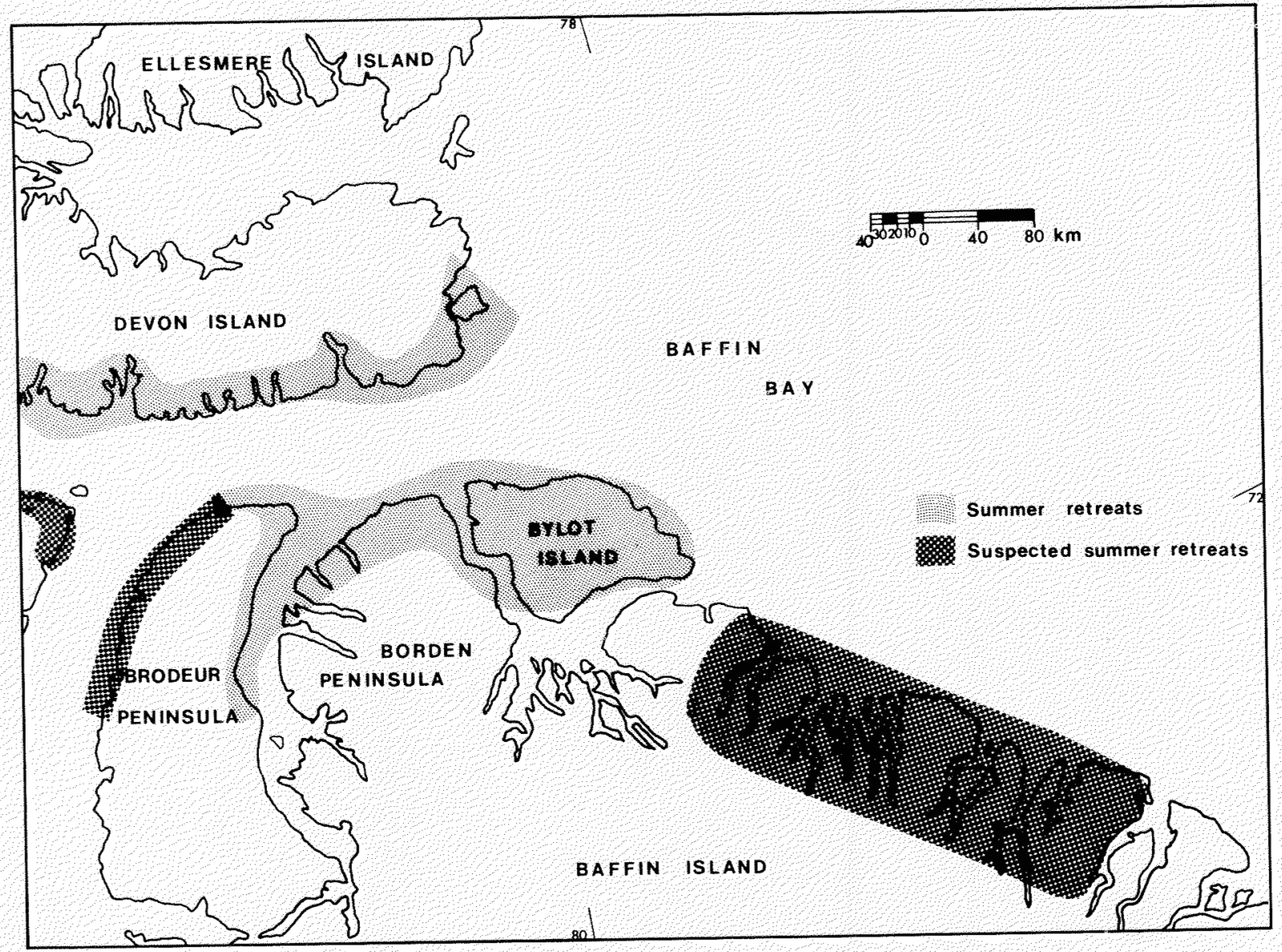

FIG. 4. Summer distribution of polar bears in the Lancaster Sound area.

TABLE 2. Average distance travelled by marked bears from their points of original capture to points of recapture or kill

\begin{tabular}{|c|c|c|c|c|c|}
\hline \multirow[b]{2}{*}{ Season of Capture } & \multirow[b]{2}{*}{ Season of Recapture or Kill } & \multicolumn{3}{|c|}{$\begin{array}{l}\text { Average Distance Between Capture } \\
\text { and Recapture or Kill }(\mathrm{km} \pm 95 \% \mathrm{CI})\end{array}$} & \multirow{2}{*}{$\begin{array}{l}\text { Test for Difference } \\
\text { Between Male and } \\
\text { Female Movements } \\
\qquad(\alpha=0.05)\end{array}$} \\
\hline & & Female & Male & $\begin{array}{l}\text { Male and Female } \\
\text { Combined }\end{array}$ & \\
\hline Late winter (March-Juné) & Late winter & $198 \pm 96(n=18)$ & $167 \pm 88(n=11)$ & $186 \pm 65(n=29)$ & $t=0.476 \mathrm{df}=27 \quad P>0.5$ \\
\hline Late winter & Fall \& mid-winter (Oct-Feb) & $244 \pm 430 \quad(n=3)$ & $387 \pm 103(n=11)$ & $357 \pm 95(n=14)$ & $t=1.33 \quad \mathrm{df}=12 \quad P>0.2$ \\
\hline Summer (June-Sept) & Late winter & $223 \pm 75(n=10)$ & $139 \pm 59 \quad(n=6)$ & $191 \pm 52(n=16)$ & $t=1.883 \mathrm{df}=14 \quad P>0.05$ \\
\hline
\end{tabular}

floe edge in 1979. There had been local concentrations of bears immediately north of Cape Hay in 1978 but this was not the case in 1979 when ice conditions were quite different (Fig. 2). In 1979 the floe edge touched shore, and for $2-3 \mathrm{~km}$ north of the cape new gray ice was followed by broken floe ice, leaving little fast ice on which bears prefer to hunt. The northeast Baffin region had the lowest capture rate ( 15.6 bears $/ 1000 \mathrm{~km}$ flown) within the study area. As in the Devon Island area, bears $(68 \% ; n=19)$ appeared to favour rough, landfast ice over floe edge $(32 \% ; n=19)$. In both 1978 and 1979, few bears were captured on the flat, shorefast ice east of Buchan Gulf.
In summer as the ice melts, some polar bears move first to deep bays containing landfast ice, and then later move onto land. Summer retreats for polar bears within the study area included: (1) the south and east coasts of Devon Island, particularly Radstock (see Stirling and Latour, 1978), Maxwell and Croker bays; (2) the shoreline and coastal mountain areas of Bylot Island; and (3) the west, north and northeast coasts of Baffin Island (Fig. 4). At these summer retreats, bears and/or tracks were seen as far as $56 \mathrm{~km}$ inland and at elevations up to $915 \mathrm{~m}$. Denning of bears at summer retreats is reported in Schweinsburg (1979). 


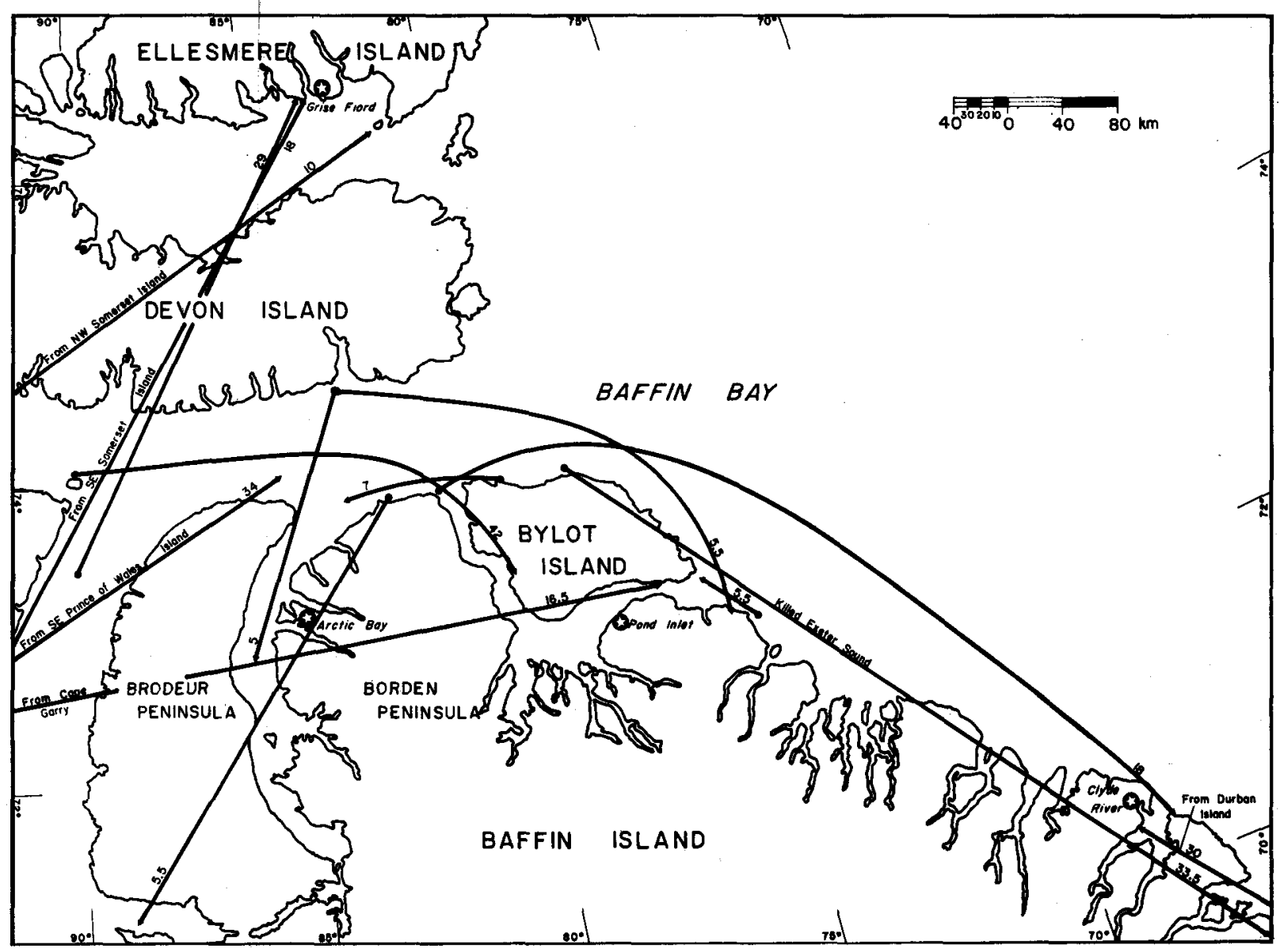

FIG. 5. Movements of polar bears captured during the late winter (mid-March to mid-June) and recaptured or killed during fall and winter (October to February) of succeeding years. Numbers are the months between capture and return.

\section{Seasonal Movements of Marked Polar Bears}

Most marked bears were recovered within a few hundred $\mathrm{km}$ of the original capture sites (Table 2). This degree of movement is consistent with other studies (Stirling $e t$ al., 1975; Schweinsburg et al., 1977; Stirling et al., 1978). However, the distance seemed to vary according to season. Polar bears killed or recaptured during the fall and mid-winter (Fig. 5) were significantly further $(t=3.098$, $\mathrm{df}=41, P<0.005$ ) from their late-winter capture sites than were those killed or recaptured during late winter (Fig. 6). This was probably a result of wide dispersal of bears during summer breakup, followed by a gradual return to the areas used in late winter.

Directional patterns of movement in relation to season were difficult to detect. However, there appeared to be an easterly movement of the bears captured between midJune and the end of August of one year, and mid-March to mid-June of succeeding years (Fig. 7). Many of the bears captured in Radstock Bay during the summer later moved to eastern Lancaster Sound. This supports the speculation that some bears move west with breakup and then gradually return as the ice re-forms.

Two bears moved long distances between their capture and recapture locations. One bear, a six-year-old male, was captured near Cape Dyer (southeast Baffin Island) in 1976 and recaptured in 1979 on southeast Bylot Island, 860 $\mathrm{km}$ away. A four-year-old male was tagged on the east coast of Prince of Wales Island in August 1977 and killed near Pond Inlet in March 1978, a distance of over $700 \mathrm{~km}$.

There did not appear to be any directional trend in movements of bears captured and resighted during the same study period, although bears captured close to shore tended to be resighted close to shore (Fig. 8). Some bears remained near capture locations, whereas others were resighted a considerable distance from their capture locations. For example, four adult females moved at least 330 $\mathrm{km}$ in two days, $260 \mathrm{~km}$ in seven days, $250 \mathrm{~km}$ in 14 days, and $225 \mathrm{~km}$ in 22 days, respectively. In contrast, two adult males were resighted no more than $5 \mathrm{~km}$ from their points of capture an average of 6.4 days later.

Eight bears crossed Lancaster Sound between the time they were captured and resighted. Two others moved between east Devon Island and south Devon Island west of Croker Bay. Clearly, most of Lancaster Sound is within the range of one population of bears.

During this study, marked bears moved between Lancaster Sound, Prince Regent Inlet, Barrow Strait, Wellington Channel and Jones Sound. Marked bears also moved 


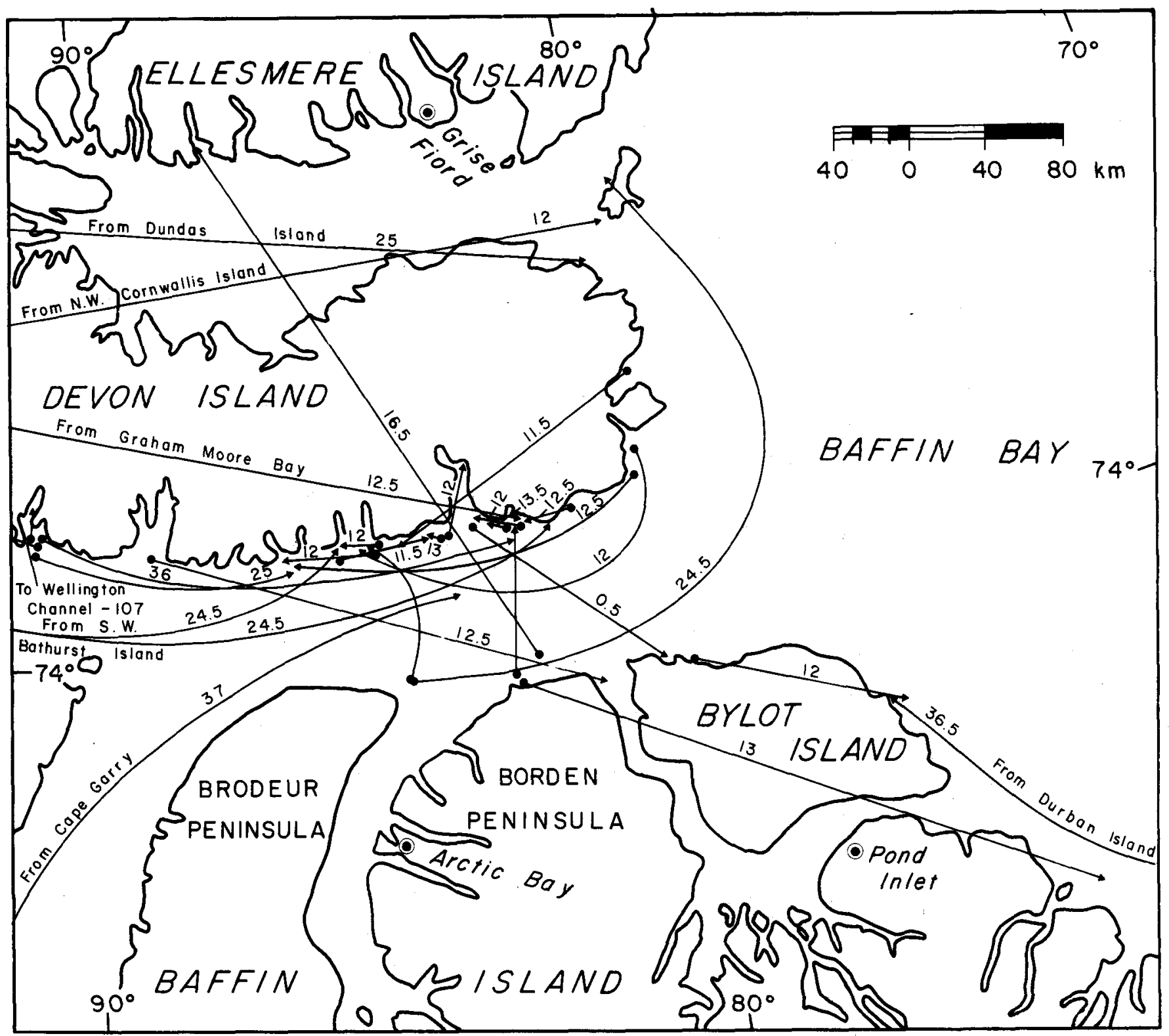

FIG. 6. Movements of polar bears captured during the late winter (mid-March to mid-June) and recaptured or killed during the same season of succeeding years. Numbers are the months between capture and return.

between Lancaster Sound and northeast Baffin Island as far south as Clyde River. These movements are consistent with the findings of Stirling et al. (1978) and show that the bears of these areas can be considered one population.

\section{Maternity Denning Areas}

Sightings of females with cubs of the year provided indirect information on denning areas within Lancaster Sound. Because cubs of the year are small and not capable of long-distance travel, females with cubs of the year sighted before the middle of April are probably close to the land area where their maternity dens are located. Family groups with newborn cubs were seen during April at Radstock and Croker bays, Cape York and Bylot Island
(Fig. 9). Maternity denning probably occurs sporadically along much of the coastal region of the study area.

Only three maternity dens have been found in the study area (Fig. 9), although seven more were reported by hunters on the east and north coasts of Bylot Island (S. Ransom, pers. comm.). Surprisingly, no dens were found on north Borden Peninsula despite the apparent presence of ideal denning habitat (Schweinsburg et al., 1977).

\section{Population Estimates}

Polar bears were captured at a higher rate in 1979 (176 bears in $7599 \mathrm{~km}$ and $146 \mathrm{~h}$ of flying) than in 1978 (56 bears in $8994 \mathrm{~km}$ and $96 \mathrm{~h}$ of flying) (Table 1). A certain amount of helicopter time is required during the immobilization 


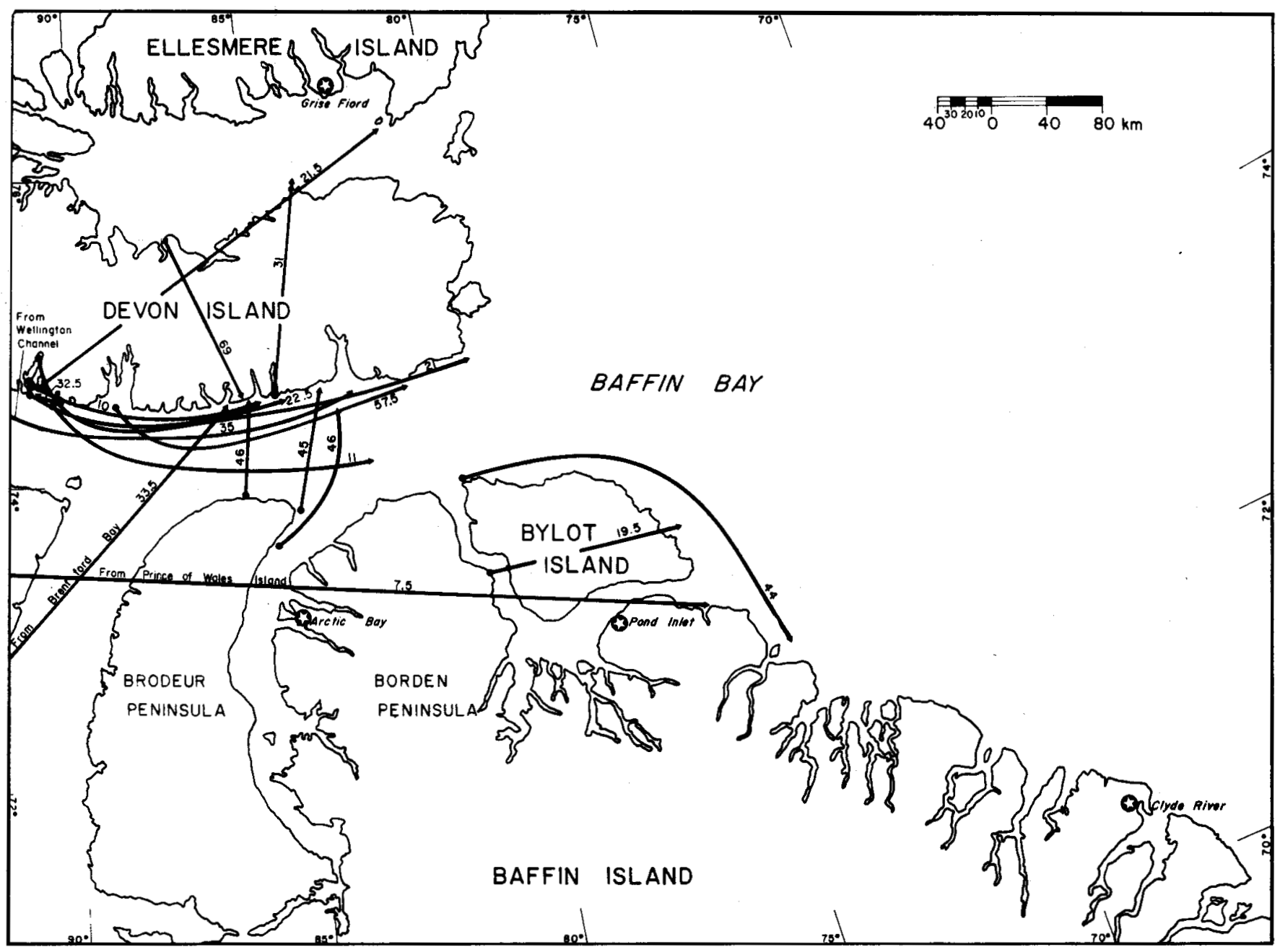

FIG. 7. Movements of polar bears captured during the summer (mid-June to the end of August) and recaptured or killed during the late winter (mid-March to mid-June) of succeeding years. Numbers are the months between capture and return.

process; hence, the shorter distance flown in 1979 reflects the larger number of bears encountered. Our most precise estimate (Table 3) of the number of bears in the Lancaster Sound study area in 1979 (Fig. 1) is $1031 \pm 236$.

\section{DISCUSSION}

\section{Population Distribution}

In the Beaufort Sea, Stirling et al. (1975) found that polar bears were most frequently sighted in active ice zones and along floe edges. Evidently unstable ice is a favoured habitat for hunting seals. In this study the greatest concentrations of bears were found off the north coast of Lancaster Sound where there is usually a floe edge polynya (frozen during our study) and associated rough ice, as well as the active floe edge at the mouth of Lancaster Sound (Smith and Rigby, 1981). Our findings are in agreement with Johnson et al. (1976) who found more bears along the north than the south side of Lancaster Sound. The higher density of bears on the north side of Lancaster Sound may also be related to the relative scarcity of Inuit hunting in that area.
The degree to which polar bears concentrate at summer retreats on land probably depends on local ice conditions. In Hudson Bay, for example, where all ice disappears in summer, bears must come ashore and localized concentrations occur along the coastline (Stirling et al., 1977). In the Arctic Islands, where summer ice conditions are more variable, polar bears do not concentrate at summer retreats to nearly the same extent. In Lancaster Sound, there is evidence that some bears come onto land (Schweinsburg et al., 1977), some move to areas of permanent ice (Stirling et al., 1978, Stirling and Latour, 1978) and others remain on pack ice (Johnson et al., 1976). Schweinsburg et al. (1977) reported that all age and sex classes of bears except adult males were present in capture samples at summer retreats; however, the sample was small. Adult males may spend the summer on pan ice but also may occasionally wander ashore.

Four female bears fitted with satellite-monitored transmitters in May 1979 either stayed near shore or moved onto land by August (Schweinsburg and Lee, in prep.). Our results suggest that summer retreats in Lancaster Sound are important for females of all ages, females with 


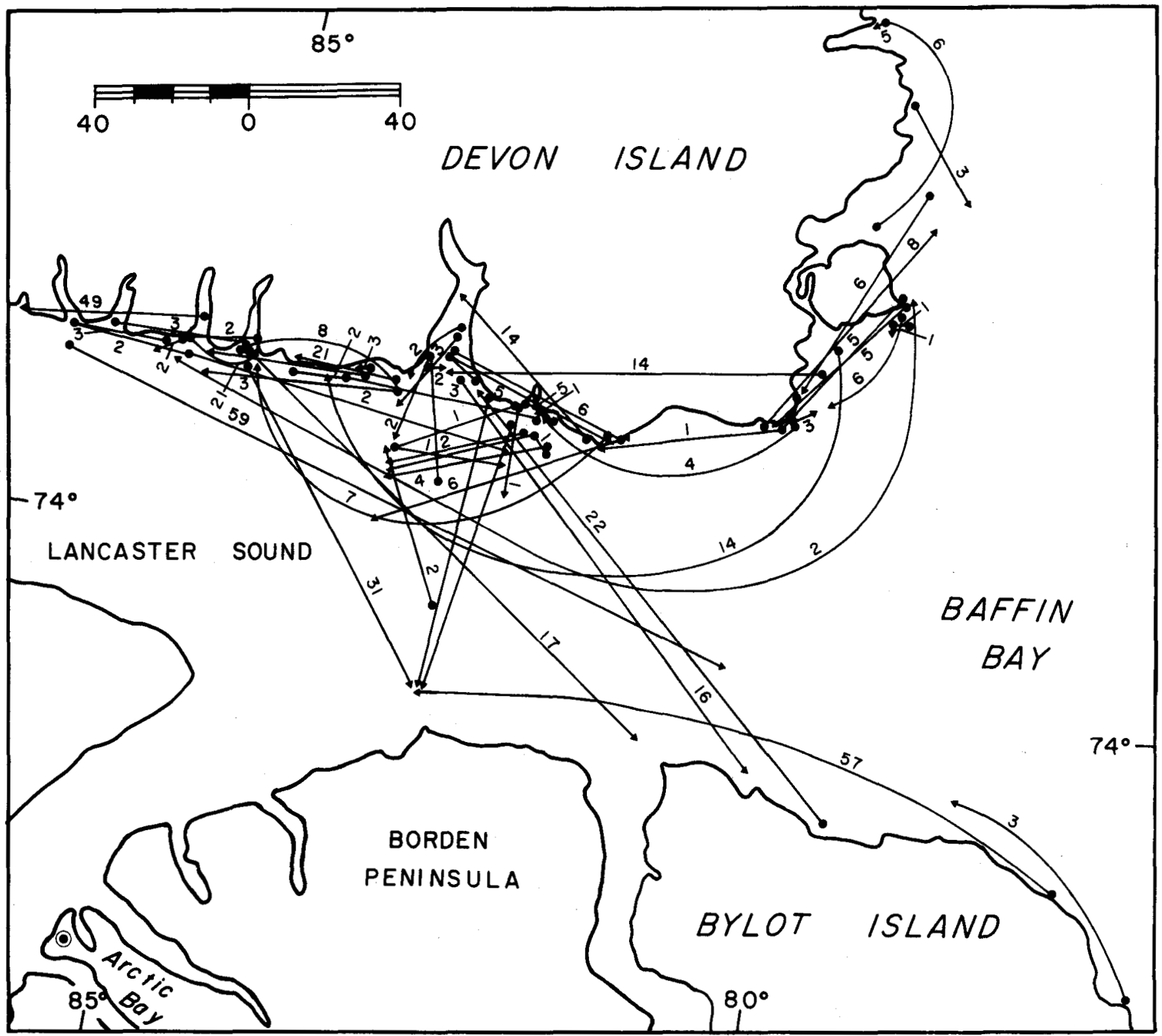

FIG. 8. Short-term movements of polar bears based on captures and resightings during April and May of 1978 and 1979. Numbers are the days between capture and resighting.

cubs, and sub-adult males, but not adult males. If this is true, the importance of summer retreats may be related to the survival of smaller or less experienced bears.

We suspect that as freeze-up progresses, bears move from summer retreats onto the ice and that their midwinter distribution is similar to that of late winter. Pregnant females probably stay close to where they spent the summer; known summer retreat areas in the NWT largely overlap denning areas (NWTWS Map Series).

\section{Population Movement Patterns}

No distinct movement patterns were detected in this study. As the ice melts from east to west, many bears probably move west to areas such as Radstock Bay and return to eastern Lancaster Sound when the ice re-forms in early winter.

The distances between late-winter capture sites and sites where bears were recaptured or killed during a subsequent fall or winter were approximately twice as long as those between late-winter capture sites and subsequent late-winter recapture or kill locations. These data suggest that bears disperse as the ice breaks up and then return to specific areas during late winter.

Most polar bears stayed within Lancaster Sound and adjacent areas such as Prince Regent Inlet, Barrow Strait, and Wellington Channel for several years after being marked, suggesting that the Lancaster Sound area is the permanent 


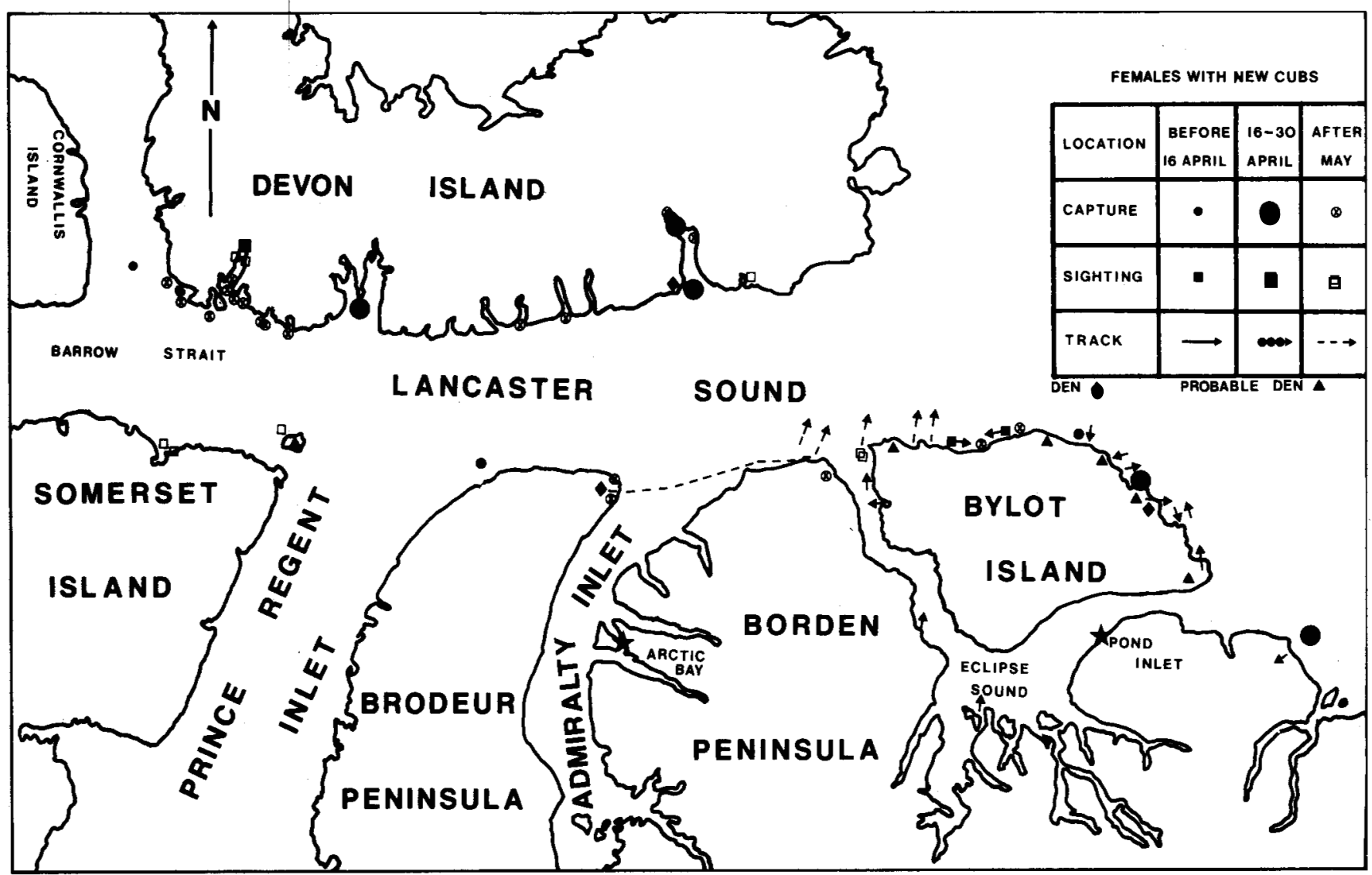

FIG. 9. Summary of information related to polar bear denning for Lancaster Sound and adjacent areas (from this study and Schweinsburg et al., 1977).

TABLE 3. Summary of mark-recapture data from eastern Lancaster Sound and estimates of the size $\left(\mathrm{N}_{\mathrm{i}}\right)$ of the polar bear population

\begin{tabular}{lcccccccc}
\hline Year & $1970 / 72$ & 1973 & 1974 & 1975 & 1976 & 1977 & 1978 & 1979 \\
\hline $\mathrm{i}$ & 1 & 2 & 3 & 4 & 5 & 6 & 7 & 9 \\
$\mathrm{n}_{\mathrm{i}}$ & 4 & 9 & 11 & 33 & 64 & 5 & 56 & 176 \\
$\mathrm{~m}_{\mathrm{i}}$ & 0 & 1 & 1 & 0 & 0 & 1 & 2 & 21 \\
$\mathrm{R}_{\mathrm{i}}$ & 3 & 9 & 11 & 29 & 64 & 5 & 55 & 175 \\
$\mathrm{P}_{\mathrm{i}}$ & - & .11 & .09 & 0 & 0 & .2 & .036 & .119 \\
$\mathrm{M}_{\mathrm{i}}$ & - & 2.66 & 9.43 & 17.20 & 40.89 & 92.83 & 85.69 & 122.74 \\
$\mathrm{~S}_{\mathrm{e}} \mathrm{M}_{\mathrm{i}}$ & - & .54 & 1.29 & 2.11 & 4.03 & 8.03 & 9.27 & 12.38 \\
$\mathrm{~N}_{\mathrm{i}}$ & - & - & - & - & - & 464 & 2380 & 1031 \\
$\mathrm{~S}_{\mathrm{e}} \mathrm{N}_{\mathrm{i}}$ & - & - & - & - & - & 416.7 & 1695.8 & 236.3 \\
\hline
\end{tabular}

$n_{i} \quad$ The total number of bears captured on the $i^{\text {th }}$ sample

$\mathrm{m}_{\mathbf{i}}$ The total number of previously marked bears captured in the $\mathrm{i}^{\text {th }}$ sample

$\mathbf{R}_{\mathrm{i}}$ The total number of marked animals (including recaptures) released in the $i^{\text {th }}$ sample

$\mathbf{P}_{i}$ The proportion of animals marked in the population

$\mathbf{M}_{\mathrm{i}}$ The number of tagged animals available for sampling just prior to the $i^{\text {th }}$ sample

$\mathrm{S}_{\mathrm{e}} \mathrm{M}_{\mathrm{i}}$ The standard error of $\mathrm{M}_{\mathrm{i}}$

$N_{i}$ The number of animals present in the populatin at time $i$

$\mathrm{S}_{\mathrm{e}} \mathrm{N}_{\mathrm{i}}$ The standard error of $\mathrm{N}_{\mathrm{i}}$

$\emptyset \quad .885$ (survival rate) home range for up to 1000 polar bears that can be considered as part of one population. The results of Løn $\varnothing(1970)$ and Larsen (1971) in Svalbard and Lentfer (1974) in Alaska also showed that bears did not wander at random, but rather within a restricted range. In this study and others (Stirling et al., 1978) some bears underwent long-distance movements. Because of our small sample size, the extent of long-distance movements and the common sex or age characteristics of the individuals are unknown. The degree of movement from our study area to Greenland is also not clear. One bear captured in Strathcona Sound, another tagged in Norwegian Bay (northwest of Jones Sound), and a third tagged at Dundas Harbour were shot in Greenland (Stirling et al., 1978). Three bears out of over 700 marked is not strong evidence for a shared population. However, because the chances of tag recovery are probably low due to less intensive Inuit hunting and a smaller research effort, the possibility of an internationally shared population cannot be ruled out. Certainly to the north where Canada approaches Greenland, the population is shared.

\section{Maternity Denning Areas}

No large concentrations of dens or family groups were found. This was also reported by Stirling et al. (1978) who concluded that sparsity of dens and family groups could be 
either a function of survey techniques or a result of the large amount of denning habitat in the Arctic Islands which allows for widely dispersed denning.

\section{Population Estimates}

Stirling et al. (1978) estimated $1647 \pm 290$ bears for the larger area (Barrow Strait, Wellington and Jones sounds, Prince Regent Inlet) around and including Lancaster Sound. On this basis, our estimate of 1031 bears for the Lancaster Sound area seems rather high. The possibility exists that there was a large influx of bears into the Lancaster Sound area during 1979 from other parts of the Arctic; however, more research is needed to determine more accurate estimates.

If there was an increase of polar bears in the study area in 1979, the reasons are unclear. In both 1978 and 1979, ice breakup in Lancaster Sound was late. Ice conditions in 1978 differed from those of 1979 in the following ways: (1) the floe edge lay some $20 \mathrm{~km}$ further west (Fig. 2); (2) Lancaster Sound and the south Devon Island area had more rough pressure ice; and (3) the landfast ice off east Devon Island broke up later. Our recapture information suggests that there may have been an influx of bears into the study area in 1979 from the west and southwest. Furthermore, a local influx of bears was detected in 1979 along the floe edge in mid-Lancaster Sound between 19 and 23 May 1979. Prior to that period, search flights along the floe edge resulted in few captured bears, but beginning on 19 May, many more bears were encountered there. Possibly those bears represented an onshore movement from Baffin Bay. Only future work in eastern Lancaster sound will determine whether 1978 and 1979 represent extremes in polar bear density, or if one year was more "typical" than the other.

\section{ACKNOWLEDGEMENTS}

Funding for this study was provided by Petro-Canada Exploration, Inc. and logistic support was obtained from the Polar Continental Shelf Project. Special help was received from G. Glazier and G. Koenig of Petro-Canada and G. Hobson and F. Alt of the Polar Continental Shelf Project. The Canadian Wildlife Service allowed the use of unpublished mark-and-recapture data for the years 1970 to 1979 . We appreciate the field assistance provided by B. Bergman of the NWTWS and D. DeMaster and M. Taylor of the USFWS. S. Buckles, Apex Helicopters Ltd. and G. Webb and L. Dean, Kenting Helicopters, provided professional and efficient helicopter service. W. Calvert, J. Takahashi and W. Nixon of the CWS, and A. Sutherland of the NWTWS did the laboratory analysis. Thanks to S. Fleck who drafted all the figures and to E. Irvine who typed and edited the manuscript. I. Stirling, CWS, provided advice and support. J. Graves and G. Calef reviewed and improved the manuscript.

\section{REFERENCES}

DeMASTER, D.O., KINGSLEY, M.C.S. and STIRLING, I. 1980. A multiple mark and recapture estimate applied to polar bears. Canadian Journal of Zoology 58:633-638.

DEPARTMENT OF INDIAN AFFAIRS AND NORTHERN DEVELOPMENT. Summary Report. 1981. Effects of crude oil on polar bears, 1981. Ottawa, Ontario. $17 \mathrm{p}$.

DUNBAR, M. and GREENAWAY, K.R. 1956. Arctic Canada from the air. Defense Research Board of Canada. Ottawa: Queen's Printer. $541 \mathrm{p}$.

JOHNSON, S.R., RENAUD, W.E., DAVIS, R.A. and RICHARDSON, W.J. 1976. Marine mammals recorded during aerial surveys of birds in eastern Lancaster Sound, 1976. LGL Ltd. Report for Norlands Petroleums Ltd. [Available from Library, Arctic Institute of North America, University of Calgary, Calgary, Alberta T2N 1N4.]

LARSEN, T. 1971. Capturing, handling, and marking polar bears in Svalbard. Journal of Wildlife Management 35:27-36.

LENTFER, J.W. 1968. A technique for immobilizing and marking polar bears. Journal of Wildlife Management 32:317-321.

L $\emptyset \mathrm{N} \emptyset, 0.1970$. The polar bear in the Svalbard area. Norsk Polarinstitutt Skrift 149. $103 \mathrm{p}$.

MILNE, A.R. and SMILEY, B.D. 1978. Offshore drilling in Lancaster Sound. Institue of Ocean Sciences, Patricia Bay. Department of Fisheries and Environment, Sidney, B.C. 95 p.

N.W.T.W.S. 1978. Map Series of Important Polar Bear Habitat. N.W.T. Wildlife Service, Yellowknife, N.W.T.

SCHWEINSBURG, R.E. 1976. Polar Bears - Research in and around Admiralty Inlet, July - August 1975. In: Kemper, B. [ed.]. Environmental Baseline Studies 1975 Strathcona Sound Program. Canadian Wildlife Service, Preliminary Report, March, 1976. Canadian Wildlife Service, Edmonton, Alberta.

1979. Summer snow dens used by polar bears in the Canadian High Arctic. Arctic 32(2): 165-169.

and L.J. Lee. (in prep.) Movement of four satellite-monitored polar bears in Lancaster Sound, Northwest Territories. Arctic.

SCHWEINSBURG, R.E., STIRLING, I., OOSENBRUG, S. and KILIAAN, H. 1977. A status report on polar bear studies in Lancaster Sound. Northwest Territories Fish and Wildlife Service Report to Norlands Petroleums Ltd. 55 p. [Available from N.W.T. Wildlife Service, Yellowknife, N.W.T.]

SMITH, M. and RIGBY, B. 1981. Distribution of polynyas in the Canadian Arctic. In: Stirling, I. and Cleator, H. [eds.]. Polynyas in the Canadian Arctic. Canadian Wildlife Service Occasional Paper No. 45:7-28.

STIRLING, I., ANDRIASHEK, D., LATOUR, P. and CALVERT, W. 1975. The distribution and abundance of polar bears in the eastern Beaufort Sea. A Final Report to the Beaufort Sea Project. Fisheries and Marine Service, Department of the Environment, Victoria, B.C. $59 \mathrm{p}$.

STIRLING, I., JONKEL, C., SMITH, P., ROBERTSON, R. and CROSS, D. 1977. The ecology of the polar bear along the western coast of Hudson Bay. Canadian Wildlife Service Occasional Paper No. 33. $64 \mathrm{p}$.

STIRLING, I. and LATOUR, P. 1978. Comparative hunting abilities of polar bear cubs of different ages. Canadian Journal of Zoology 56:1768-1772.

STIRLING, I., SCHWEINSBURG, R.E. and CALVERT, W. 1978. Polar bear population ecology - Arctic Islands pipeline route. Final Report to Environmental - Social Program, Northern Pipeline Route. ESCOM Report No. A1-24. Department of Indian and Northern Affairs, Ottawa. 93 p.

THOMAS, D.C. and BANDY, P.J. 1973. Age determination of wild black-tailed deer from dental annulations. Journal of Wildlife Management 27(2):323-335. 